\title{
Pendampingan dan Pelatihan Pengelolaan Limbah Organik Menjadi Produk Bernilai Ekonomi di SMA Negeri 1 Bengkayang
}

\author{
Aloysius Hari Kristianto ${ }^{1}$ \\ Sekolah Tinggi Ilmu Manajemen Shanti Bhuana, aloysius.hari@shantibhuana.ac.id \\ Pramatatya Resindra Widya ${ }^{2}$ \\ Sekolah Tinggi Ilmu Manajemen Shanti Bhuana, pramatatya@shantibhuana.ac.id
}

\begin{abstract}
Abstrak
Tujuan dari aktivitas pengabdian masyarakat ini adalah untuk merubah, melatih dan mengembangkan pola pikir siswa/i SMA Negeri 1 Bengkayang mengenai sumber daya produksi berupa sampah organik yang selama ini hanya dibuang dan dibiarkan begitu saja. Sampah organik tersebut dapat dikelola dan diolah menjadi produk bernilai ekonomi yaitu pupuk cair organik. Aktivitas kegiatan menggunakan project based learning methods yang meliputi ceramah dan diskusi kelompok mengenai circular economy dan dampak negatif dan manfaat dari sampah organik (sisa makanan, limbah buah dan limbah sayur) rumah tangga, serta pelatihan membuat pupuk cair dari limbah organik dengan media tong komposter dan juga pelatihan sederhana mengenai desain produk ( pengemasan dan branding) hingga proses pemasaran. Hasil dari program pengabdian masyarakat ini adalah kesadaran siswa/ i mengenai pentingnya mengelola sampah dengan benar dengan memanfaatkannya menjadi produk bernilai ekonomi dan produk yang dihasilkan yang siap untuk dipasarkan di masyarakat.
\end{abstract}

Kata Kunci: project based learning methods, sampah organik, produk bernilai ekonomi, circular economy

\begin{abstract}
The purpose of this public service activity is to change, train and develop the mindset of students of SMA Negeri 1 Bengkayang regarding production resources in the form of organic waste which has only been thrown away and left alone. Organic waste can be managed and processed into economic value products, namely organic liquid fertilizer. Activity activities using project-based learning methods which include lectures and group discussions on the circular economy and negative impacts and benefits of organic waste (food scraps, fruit waste and vegetable waste) household, as well as training in making liquid fertilizer from organic waste with composter barrel media and also simple training on product design (packaging and branding) to the marketing process. The results of this community service program are students' awareness of the importance of managing waste properly by utilizing it to be of economic value and produced products that are ready to be marketed in the community.
\end{abstract}

Keywords: project-based learning methods, organic waste, economic value products, circular economy 


\section{Pendahuluan}

Secara khusus manusia sebagai mahkluk sosial yang mempunyai akal dan budi menempati posisi tertinggi dalam sebuah ekosistem di bumi yang bertempat di lingkungan di mana semua mahkluk hidup di dalamnya. Hasil studi Hendrik L. Blum, 1974 dalam Slamet 2016 menyatakan bahwa lingkungan merupakan faktor utama yang mempengaruhi derajat kesehatan, manusia / masyarakat sebagai pemeran utama bertanggung jawab untuk menjaga dan merawatnya. Dalam menjaga lingkungan peran masyarakat sangat penting, karena masyarakat dituntut dapat mampu menyelesaiakan masalah yang terkait dengan ketahanan lingkungan hidup. Permasalahan yang sering timbul dalam masyarakat pada umumnya adalah berkaitan dengan pembuangan akhir / limbah / sampah rumah tangga, diperlukan kesadaran tentang pentingnya pengelolaan limbah dengan baik dan benar dengan tetap menjaga keberlanjutan lingkungan sekitar (Luthfi \& Kismini, 2013).

Limbah / sampah merupakan hasil pembuangan konsumsi masyarakat yang tidak dipergunakan kembali. Sudut pandang yang keliru / negatif dari masyarakat yang menganggap bahwa sampah adalah hal yang kotor dan menjijikkan yang seharusnya dibuang atau dibakar sebagaimana seharusnya (Mulasari, 2013). Aktivitas / hasil konsumsi masyarakat yang kerap menimbulkan efek eksternalitas negatif tidak hanya menjadi tanggung jawab pemerintah daerah namun merupakan tanggung jawab bersama antara pemerintah dan masyarakat terutama terkait dengan tata kelola sampah yang benar supaya tidak menimbulkan dampak negatif pada lingkungan (Hardiatmi, 2011). Sampah merupakan masalah aktual yang terjadi di masyarakat sampai dengan saat ini, terutama terkait dengan pengelolaan yang tidak benar secara khusus di Indonesia. Semakin tinggi tingkat jumlah penduduk maka produktivitas sampah juga akan semakin meningkat, karena tingkat konsumsi masyarakat semakin tinggi (Mahyudin, 2017). Kurangnya dasar hukum yang tegas, tempat pembuangan sampah yang tidak memadai, kurangnya usaha dalam melakukan pengomposan dan kurangnya TPA dengan sistem pengelolaan yang tepat merupakan beberapa masalah yang terjadi di Indonesia yang terkait dengan pengelolaan sampah serta masih perlu ditingkatkannya sosialisasi serta pendampingan mengenai pendidikan lingkungan yang terkait dengan partispasi publik dalam hal tata kelola sampah yang benar dan baik (Chaerul et al., 2007). Kesadaran dan pengetahuan masyarakat akan sampah dapat memberikan nilai ekonomis ketika sampah dijadikan sebagai sumber daya yang bermanfaat dengan selalu berprinsip pada konsep 3R (Reduce, Reuse, Recycle) yang dapat menghasilkan sebuah produk yang bermanfaat (Setianingrum, 2018). Pentingnya keterlibatan dari berbagai pihak seperti keluarga, komunitas peduli lingkungan, pihak sekolah dan pemerintah untuk mendukung dan memberikan stimulus kepada kaum muda agar sadar akan keberlanjutan lingkugan dengan pemanfaatannya menjadi sebuah produk bernilai jual (Kristianto, 2018).

Hasil observasi awal menunjukkan bahwa kondisi sampah disekolah masih dibiarkan begitu saja, sampah organik terutama daun kering masih dibakar, sisa makanan ditimbun ditanah dan belum diolah. Dengan pengolahan yang tepat dan 
benar sampah organik ini dapat dijadikan nilai manfaat berupa pupuk kompos yang dapat memenuhi standar yang telah ditetapkan pemerintah berupa SNI (Rahmawanti \& Dony, 2014). Faktor yang mempengaruhi hal tersebut adalah guru, siswa dan anggota disekolah belum begitu memahami bagaimana mengelola sampah dengan benar yang dapat menghasilkan produk bernilai ekonomi dan masih jarang adanya pendampingan dan pelatihan mengenai waste management di lingkungan sekolah. Melalui program ini diharapkan dapat mengubah pola pikir dan cara pandang siswa untuk meningkatkan kreatifitas dan berinovasi dalam mengelola sampah menjadi barang produktif.

Dalam mengimplementasikan hal tersebut diatas maka tujuan dan manfaat dari program pengabdian masyarakat ini adalah :

1) Mengubah pola pikir dan memperdalam konsep $3 R$ (Reduce, Reuse, Recycle) pada siswa dalam mengelola sampah yang benar menjadi produk bernilai ekonomi.

2) Melatih siswa dalam proses pembuatan pupuk organik secara sederhana dengan bahan yang mudah didapat.

3) Memberikan pelatihan mengenai branding dan proses pemasaran melalui media yang ada secara efektif dan effisien

\section{Metode}

Program pengabdian masyarakat ini dilaksanakan dengan sistem pendampingan dan pelatihan pengelolaan limbah organik menjadi produk bernilai ekonomi kepada siswa SMAN 1 Bengkayang yang tergabung dalam komunitas adiwiyata yang beranggotakan 40 orang. Waktu pelaksanaan kegiatan ini selama 6 (enam) bulan pada bulan Juni - Desember 2019 dilakukan 5 kali pertemuan pokok disamping pemantauan secara berkala seminggu sekali untuk meninjau proses penguraian sampah menjadi pupuk cair dengan jadwal kegiatan menyesuiakan waktu kegiatan komunitas adiwiyata SMAN 1 Bengkayang. Program kegiatan ini menggunakan metode project based learning dengan cara sebagai berikut :

1) Cara 1 (pertama) - Ceramah dan diskusi :

Peserta diberikan wawasan mengenai literasi konsep $3 R$ (reduce, reuse, recycle) dan literasi sistem pengelolaan sampah organik.

2) Cara 2 (kedua ) - Tutorial :

Peserta diberikan materi bagaimana membuat tong komposter dan pupuk cair organik dengan bahan sampah organik rumah tangga.

3) Cara 3 ( Ketiga ) - Pelatihan / praktik:

Peserta diberikan kesempatan untuk mempraktikkan hasil pemaparan materi yang sudah disampaikan yang terkait dengan pengelolaan sampah organik sampai dengan proses pemasaran.

Waktu pelaksanaan kegiatan ini selama 6 (enam) bulan pada bulan Juni - Desember 2019 dilakukan 6 kali pertemuan pokok disamping pemantauan secara berkala seminggu sekali untuk meninjau proses penguraian sampah menjadi pupuk cair dengan jadwal kegiatan menyesuiakan waktu kegiatan komunitas adiwiyata SMAN 1 Bengkayang, dengan pertemuan kegiatan sebagai berikut: 
Tabel 1. Kegiatan pertemuan

\begin{tabular}{cccc}
\hline No & Pertemuan ke - & Kegiatan & Materi \\
\hline 1 & Pertemuan 1 & Ceramah \& Diskusi & $\begin{array}{c}\text { Konsep 3R (Reduce, Reuse, Recycle) berbasis } \\
\text { masyarakat dan perubahan paradigma dari konsep } \\
\text { linear economy menjadi konsep circular economy. }\end{array}$ \\
2 & Pertemuan 2 & $\begin{array}{c}\text { Ceramah, Diskusi \& } \\
\text { Tutorial }\end{array}$ & $\begin{array}{c}\text { Cara membuat tong komposter dengan bahan apa } \\
\text { saja yang diperlukan disertai tutorial dari youtube } \\
\text { dan video pribadi cara pembuatan komposter. }\end{array}$ \\
3 & Pertemuan 3 & $\begin{array}{c}\text { Ceramah, Diskusi \& } \\
\text { Tutorial }\end{array}$ & $\begin{array}{c}\text { Proses branding hingga pemasaran produk yang } \\
\text { sudah siap dijualbelikan. }\end{array}$ \\
4 & Pertemuan 4 & $\begin{array}{c}\text { Pelatihan / Praktik } \\
\text { Pelatihan / Praktik }\end{array}$ & $\begin{array}{c}\text { Pembuatan tong komposter } \\
\text { Pembuatan pupuk cair dengan bahan limbah / } \\
\text { sampah organik rumah tangga dan proses branding } \\
\text { produk. }\end{array}$ \\
\hline
\end{tabular}

Program kegiatan ini dikatakan berhasil jika siswa SMAN 1 Bengkayang memahami pentingnya pengelolaan sampah organik yang benar dengan menghasilkan sebuah produk pupuk cair organik yang bernilai ekonomi dengan merek tertentu.

\section{Hasil dan Pembahasan}

Dari kegiatan pelaksanaan pengabdian masyarakat dengan program pendampingan dan pengelolaan limbah organik menjadi produk bernilai ekonomi di SMAN 1 Bengkayang menghasilkan beberapa poin sebagai berikut :

1) Peserta siswa komunitas adiwiyata SMAN 1 Bengkayang telah mengerti dan memahami tata kelola sampah yang benar dengan konsep 3R (Reduce, Reuse, Recycle), materi mengenai perubahan konsep linear economy menjadi circular economy berbasis masyarakat dan proses branding hingga pemasaran.

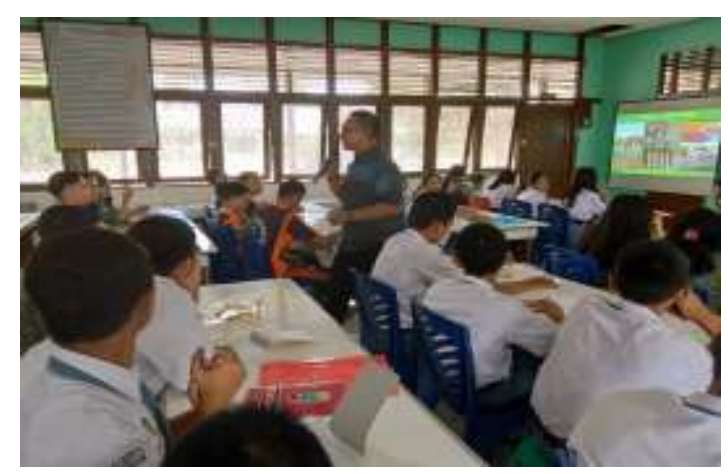

(a)

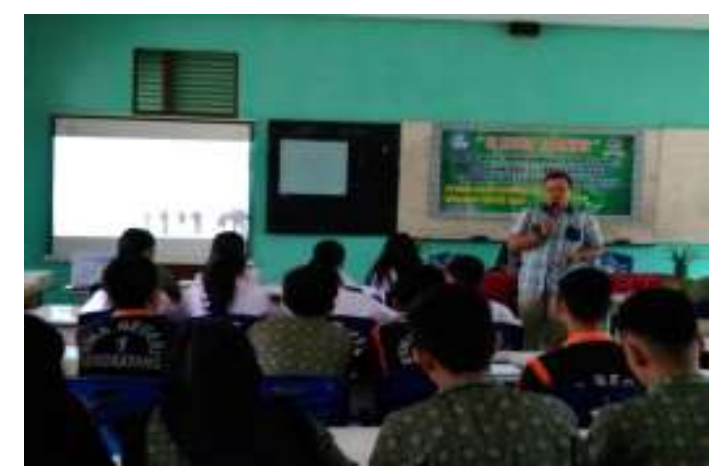

(b)

Gambar.1 (a \& b) Ceramah dan diskusi dengan materi konsep 3R, Linear economy, Circular Economy, branding dan pemasaran 
Ada beberapa informasi yang dapat dikumpulkan dari hasil ceramah dan diskusi dengan peserta selama kegiatan berlangsung, yaitu: adanya beberapa kendala yang dihadapi para siswa komunitas adiwita yaitu pola pikir para siswa SMAN 1 Bengkayang dalam membuang sampah dan minimnya pengetahuan mengenai nilai lebih dari sampah, yang membuat mereka tidak peduli terhadap hasil buangan / limbah ini. Selain itu para guru dan staf sekolah sulit untuk mensosialisasikan mengenai tata kelola sampah kepada para siswa sedangkan dari sisi sarana dan prasarana belum lengkap dan belum paham apa saja yang diperlukan. Maka tidak heran apabila dari hasil diskusi dengan peserta pelatihan diperoleh informasi bahwa perlunya perubahan pola pikir mengenai manfaat sampah dan terkendala produk apa yang bisa diciptakan dari sampah organik tersebut. Dalam pemaran materi juga ditekankan akan pentingnya konsep circular economy yaitu sebuah konsep yang memanfaatkan hasil buangan sebagai sumber daya untuk menciptakan produk baru tanpa merusak lingkungan, lain halnya dengan konsep linear economy yang lebih menghasilkan buangan dari sisa konsumsi masyarakat, konsep ini di jelaskan secara sederhana dengan mengutamakan konsep $3 R$ (reduce, reuse, recycle). Konsep circular economy diharapkan dapat memberikan solusi mengenai masalah lingkungan yang saat ini dihadapi dunia yang memadukan antar disiplin ilmu seperti kewirausahaan, ilmu lingkungan dan ilmu mengenai pembangunan berkelanjutan (Sauvé et al., 2016). Penjelasan proses branding dan pemasaran pun juga dijelaskan dalam ceramah dan diskusi ini membahas tentang bagaimana membuat logo dan nama merek yang mudah dikenal dan diingat oleh konsumen, dan cara pemasaran melalui media sosial jika produk ini siap untuk diperjualbelikan disertai dengan beberapa tutorial melalui video dan youtube. Branding sebuah produk merupakan salah satu faktor yang berperanan dalam hal melindungi, memegang, menjaga, melestarikan dan mengidentifikasi produk yang bertujuan untuk memfasilitasi komersialisasi dan penggunaannya (Omar et al., 2011) .

2) Peserta siswa / komunitas adiwiyata berhasil membuat tong komposter secara sederhana dan lebih sadar dalam membuah sampah dilingkungan sekolah dengan memilih dan memisah antara sampah organik dan sampah anorganik.

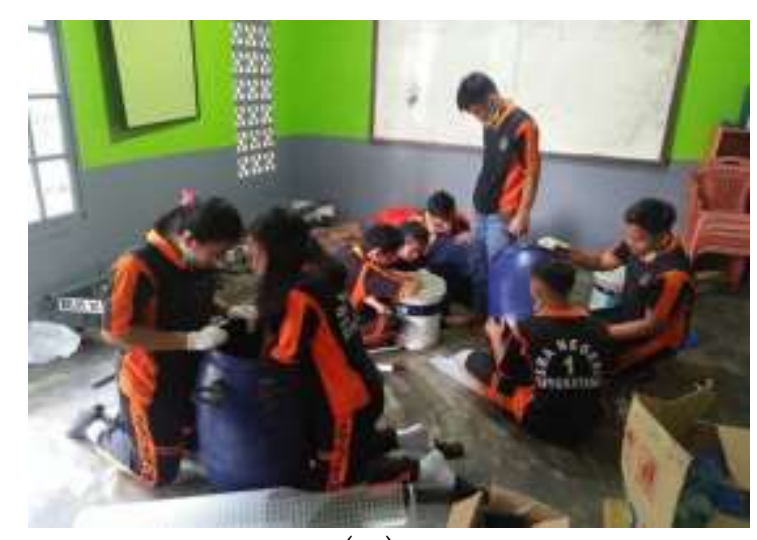

(c)

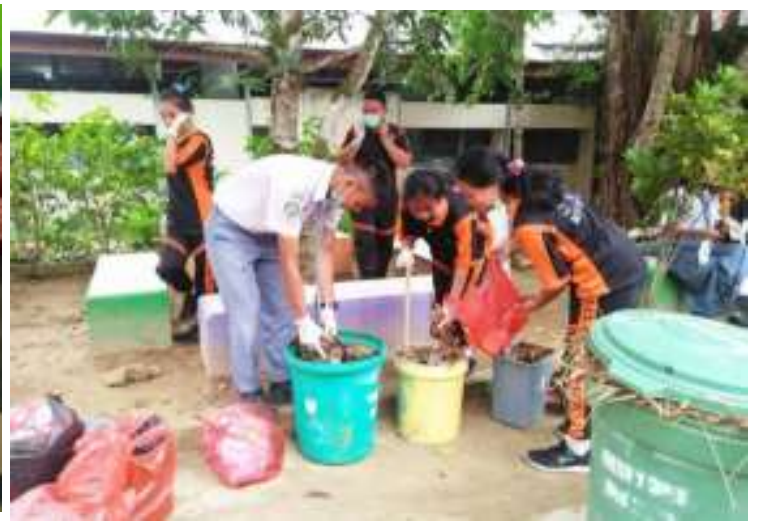

(d)

Gambar.2 (c \& d) Praktik membuat tong komposter dari tong bekas dan proses memilih dan memilah sampah sekitar lingkungan sekolah 
Kegiatan praktik pembuatan komposter dilakukan bersamaan dengan proses pemilihan dan pemisahan sampah dengan membersihkan lingkungan sekolah dari sampah organik yang bisa digunakan sebagai bahan pembuat pupuk organik cair. Hal ini dilakukan secara periodik oleh siswa komunitas adiwita supaya memberikan contoh dan cara mengelola sampah yang benar kepada siswa lain hal ini diharapkan dapat mengubah stigma bahwa sampah merupakan sumber daya yang dapat menciptakan nilai ekonomi.

3) Peserta siswa / komunitas adiwiyata sudah dapat menghasilkan produk pupuk cair dari pengolahan limbah organik di lingkungan sekolah SMAN 1 Bengkayang dengan merek "SMADIW" dan sudah dalam bentuk kemasan siap jual. Metode project based learning memberikan alternatif pilihan dalam meningkatkan jiwa kewirausahaan untuk kaum muda karena metode yang diberikan bersifat sistematis dan terkonsep dari proses awal hingga akhir yang mendorong kaum muda untuk dapat mengeksplorasi kreatifitas dan berinovasi dalam berkarya dalam menciptakan produk yang berbasis ramah lingkungan (Rahayu, 2018). Banyak potensi inovatif pengusaha berwawasan lingkungan dengan tujuan untuk mendorong lebih banyak startup yang akan menciptakan teknologi lingkungan yang diperlukan untuk mengatasi masalah lingkungan kita. Hal ini dapat diterapkan dalam tingkat sekolah/ universitas dengan membahas peran pendidikan kewirausahaan dalam mempromosikan perilaku ramah lingkungan dengan mengintergarsaikan dalam bentuk kurikulum berbasis ecopreneurship (McEwen, 2013). Siswa juga diberikan materi mengenai bagaimana melakukan komunikasi pemasaran yang lebih efektif dan efisien dengan pendekatan aspek rasional kepada calon pembeli mengenai kelebihan pupuk organik yang mereka produksi (Widya, 2019)

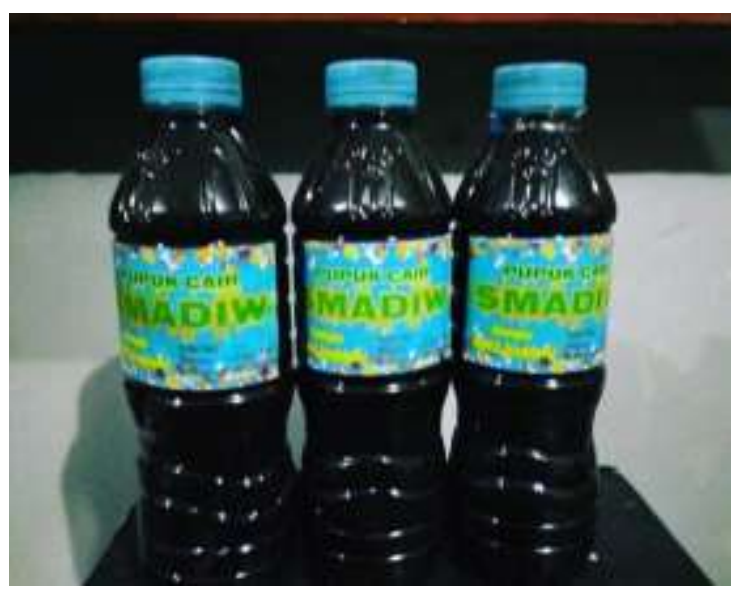

( e )

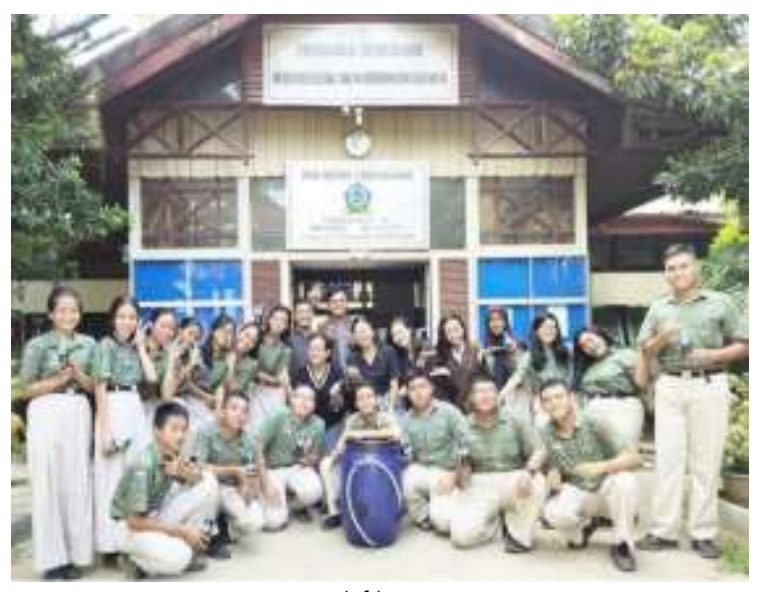

(f)

Gambar.3 (e \& f) hasil tong komposter yang sudah jadi dan hasil pupuk cari "SMADIW" yang siap dipasarkan

\section{Simpulan dan Rekomendasi}

Kesimpulan dari program pengabdian pada masyarakat pendampingan dan pelatihan pengelolaan limbah organik menjadi produk bernilai ekonomi di SMAN 1 
Bengkayang ini adalah para peserta siswa komunitas adiwiayata telah memahami dan mengetahui lebih banyak mengenai tata kelola sampah sistem $3 R$ (reduce, reuse, recycle) yang benar dengan konsep circular economy berbasis masyarakat serta mampu membuat produk dari limbah organik dengan brand yang sederhana dan menarik serta memahami proses pemasaran yang efektif dan efisien, hal ini terlihat dari animo siswa mengikuti pendampingan dan pelatihan dari awal sampai dengan akhir proses menjadi sebuah produk yang siap untuk diperjualbelikan. Dan juga peserta mampu mengimplementasikan program yang diberikan di lingkungan sekolah SMAN 1 Bengkayang. Program ini merupakan salah satu langkah yang dilakukan dalam mengimplementasikan program ekonomi hijau dalam kewirausahaan hijau dengan mempertimbangkan aspek keberlanjutan (Djatmika, 2012).

\section{Acknowledgements}

Tim peneliti ucapkan puji syukur atas terselesainya program kegiatan pengabdian pada masyarakat dengan tepat waktu. Terima kasih kepada pihak PRPM ( Ibu Deffrinica, S.E., M.E), Sekolah Tinggi Ilmu Manajemen (STIM) Shanti Bhuana Bengkayang ( Bp Marianus Dinata Alnija, S.S., M.Hum) dan SMAN 1 Bengkayang selaku Mitra ( Ibu Digna Rita.,M.Pd dan Ibu Agustina Rina P, S.Pd ) yang sudah mendukung dan membantu pelaksanaan kegiatan pengabdian ini. Terima kasih juga untuk tim inti dari mahasiswa STIM Shanti Bhuana Bengkayang ( Petrus Benny KWU 2017, John Darwis - KWU 2017, Evarista Eva - MNJ 2017 dan Oliviana Santaria - MNJ 2018) yang telah membantu hingga program ini berjalan dengan baik dan lancar.

\section{Daftar Pustaka}

Chaerul, M., Tanaka, M., \& Shekdar, A. V. (2007). Municipal Solid Waste Management in Indonesia: Status and the Strategic Actions. Journal of the Faculty Environmnetal Science and Technology, Okayama University, 12(I), 41-49.

Djatmika, E. T. (2012). Mempersiapkan Green Entrepreneurs Untuk Pembangunan Berkelanjutan.

http://digilib.um.ac.id/images/stories/pidatogurubesar/2012/mempersiapka

$\mathrm{n}$ green entrepreneurs untuk pembangunan berkelanjutan - ery tri djatmika.pdf

Hardiatmi, S. (2011). Pendukung keberhasilan pengelolaan sampah kota. Jurnal Inovasi Pertanian, 10, 50-66.

Kristianto, A. H. (2018). Development Of Interest In Youth Entrepreneurship In Utilizing Organic Waste Into Selling Product In The Border Area. Prosiding International Conference on Information Technology and Business (ICITB), 228-236.

Luthfi, A., \& Kismini, E. (2013). Partisipasi Masyarakat Dalam Sistem Pengelolaan Sampah Di Tpa Sukoharjo Kabupaten Pati. Jurnal Abdimas, 17(1), 13-20.

Mahyudin, R. P. (2017). Kajian Permasalahan Pengelolaan Sampah Dan Dampak. Teknik Lingkungan, 3, 3(1), 66-74.

McEwen, T. (2013). Ecopreneurship as a Solution to Environmental Problems: 
Implications for College Level Entrepreneurship Education. International Journal of Academic Research in Business and Social Sciences, 3(5), 264-288.

Mulasari, S. A. (2013). Hubungan Tingkat Pengetahuan Dan Sikap Terhadap Perilaku Masyarakat Dalam Mengolah Sampah Di Dusun Padukuhan Desa Sidokarto Kecamatan Godean Kabupaten Sleman Yogyakarta. Jurnal Kesehatan Masyarakat (Journal of Public Health), 6(3). https:/ / doi.org/10.12928/kesmas.v6i3.1055

Omar, M. W., Fadzil, M. I., Ali, M. N. M., \& Shaharudin, M. R. (2011). The Effectiveness of Bumiputra SME Food Product Packaging in the Malaysian Customers ' Perception. Canadian Social Science, 7(2), P102-109. http://cscanada.net/index.php/css/article/view/1235

Rahayu, S. (2018). Development Of Student Ecopreneurship Potential Through Learning Based Projects Model In Social Studies Learning (Classroom Action Research in Class VII-A MTs Ar-Rohmah Bandung). International Journal Pedagogy of Social Studies, 2(2), 59. https://doi.org/10.17509/ijposs.v2i2.10166

Rahmawanti, N., \& Dony, N. (2014). Pembuatan Pupuk Organik Berbahan Sampah Organik Rumah Tangga Dengan Penambahan Aktivator EM 4 Di Daerah Kayu Tangi. Ziraa'ah Majalah Ilmiah Pertanian, 39(1), 1-7.

Sauvé, S., Bernard, S., \& Sloan, P. (2016). Environmental sciences, sustainable development and circular economy: Alternative concepts for trans-disciplinary research. Environmental Development, 17, 48-56. https://doi.org/10.1016 /j.envdev.2015.09.002

Setianingrum, R. budi. (2018). Pengelolaan Sampah Dengan Pola 3 R Untuk Memperoleh Manfaat Ekonomi Bagi Masyarakat. BERDIKARI : Jurnal Inovasi Dan Penerapan Ipteks, 6(2), 173-183. https:// doi.org/10.18196/bdr.6244

Widya, P. R. (2019). Rational Appeal Vs Emotional Appeal In Forming Consumer's Interest Through Advertisement. 1(1), 60-67. 